\title{
Police-Citizen Encounters That Involve Mental Health Concerns: Results of an Ontario Police Services Survey
}

\author{
Janet Durbin \\ Centre for Addiction and Mental Health, and University of Toronto \\ Elizabeth Lin \\ Centre for Addiction and Mental Health, Institute for Clinical Evaluative Sciences, \\ and University of Toronto \\ Natalia Zaslavska \\ Centre for Addiction and Mental Health
}

\begin{abstract}
The present study surveyed police services in Ontario to learn about changes in volume of contacts with persons with mental illness and use of pre-arrest diversion practices between 2003 and 2007, when significant new funding was provided to community mental health services. Participants included $37 \mathrm{mu}-$ nicipal services (54\% of services serving $92 \%$ of provincial population) and the Ontario Provincial Police. Findings indicated a trend of increasing police encounters with persons with mental illness. Police services had a range of diversion practices in place although actual implementation was lower. Some of these practices were implemented after 2005, coinciding with the entry of the new resources, although other system activities during that period also promoted police-mental health system collaboration and pre-arrest diversion. Police
\end{abstract}

Janet Durbin, Health Systems Research and Consulting Unit, Centre for Addiction and Mental Health, and Department of Psychiatry, University of Toronto, Ontario; Elizabeth Lin, Health Systems Research and Consulting Unit, Centre for Addiction and Mental Health, Institute for Clinical Evaluative Sciences, and Department of Psychiatry, University of Toronto, Ontario; Natalia Zaslavska, Health Systems Research and Consulting Unit, Centre for Addiction and Mental Health, Toronto, Ontario.

This work was funded on a grant from the Ministry of Health and Long-Term Care through the Ontario Mental Health Foundation. We are grateful to the Ontario Association of Chiefs of Police, and the Operational Policy and Strategic Planning Bureau of the Ontario Provincial Police for their support. Our thanks also go to municipal police services and the OPP Research and Policy Section for providing data. Our advisory group and community stakeholders provided valuable feedback during survey development. The opinions, results, and conclusions are those of the authors, and no endorsement by the Ontario Ministry of Health and Long-Term Care is intended or should be inferred.

Correspondence concerning this article should be addressed to Janet Durbin, Health Systems Research and Consulting Unit, Centre for Addiction and Mental Health, 33 Russell Street, Toronto ON M5S 2S1. Email: janet_durbin@camh.net 
service ability to report data improved over the study period, but common reporting practices are lacking. Continuing work to create a provincial standardized database of police-citizen encounter data would facilitate efforts to better understand when and how diversion practices are implemented and with what results.

Concerns about the criminalization of people with mental illness have emerged in recent decades, often linked to the large-scale closure of inpatient beds starting in the 1960s and the resulting increase of individuals trying to manage in the community (Cordner, 2006; Lamb \& Weinberger, 2005; Lamb, Weinberger, \& DeCuir, 2002). With an inadequate supply of services and resources to support these individuals, the belief has been that many ended up involved in the criminal justice system. This phenomenon has been referred to as "re-institutionalization," with responsibility for persons with mental illness shifting from the psychiatric facility to the jail (Priebe et al., 2005). A U.S. study concluded that "in 1955, 0.3\% of the U.S. population was mentally ill and residing in an institution; whereas in 1999, $0.3 \%$ of the U.S. population [was] mentally ill and [was] in the criminal justice system" (Borum, 2000). ${ }^{1}$ More recent estimates of the percentage of inmates in U.S. jails who have serious mental illness range from 10 to 27\% (National Alliance on Mental Illness, 2004). Similar rates have been reported in Canada (Bland, Newman, Thompson, \& Dyck, 1998).

Police are the first point of contact with the criminal justice system, and officers are assuming an increasing role as first-time responders for persons with mental health concerns (Cotton, 2004). Deane and colleagues (Deane, Steadman, Borum, Veysey, \& Morrissey, 1999) estimated that $7 \%$ of police contacts in a sample of U.S. jurisdictions with 100,000 or more people involved people with mental illness, and Borum and colleagues (Borum, Deane, Steadman, \& Morrissey, 1998) reported an average of six encounters per month per patrol officer with citizens with mental illness in a survey of patrol officers in three U.S. cities. Waldman (2004) estimated that the New York City Police Department responds to about 150,000 "emotionally disturbed persons" calls per year.

Canadian data are also beginning to emerge. Crocker, Hartford, and Heslop (2009) applied rigorous criteria to a police service administrative database and estimated that interactions with persons with serious mental illness constituted about $3 \%$ of all police-citizen contacts from 2000 to 2005 . In a Toronto-area study, Matheson et al. (2005) reported an annual rate of suicide-related calls to police of 1.9 per 1,000 dispatched calls from 1997 to 2001, or about 1,400 calls annually. A Vancouver study (Wilson-Bates \& Chu, 2008) found mental health to be a contributing factor in $31 \%$ of police-attended calls in a 2 -week prospective study. This rate was based on patrol officer feedback rather than more objective criteria.

While the methods of estimating police involvement with persons with mental illness and the results vary, a role for police officers is evident. Moreover, the burden associated with managing mental healthrelated calls can be greater than the time spent on calls for traffic injury accidents, burglaries, or felony assaults (Cordner, 2006). In a survey of police officers, 48\% agreed that people with mental illness take up more than "their fair share of police time" (Cotton, 2004, p. 139). Visits that result in an apprehension under the Ontario Mental Health Act and involuntary transfer to the emergency department (ED) can be particularly time consuming. There may be long waiting periods when police officers cannot attend to other 
duties. Moreover, if individuals are quickly released, a revolving door situation may result where officers encounter the same individuals again and again in the community (Lamb et al., 2002; Matheson et al., 2005). Rates of police referrals to the ED for persons with mental illness can be significant, with several recent U.S. studies estimating police referrals to be $18-26 \%$ of all mental health ED referrals (Fry \& Brunero, 2005; Lee, Brunero, Fairbrother, \& Cowan, 2008; Redondo \& Currier, 2003).

The idea that unnecessary criminalization of people with mental illness results in part from inadequate resources for community mental health care is frequently raised (Lamb \& Weinberger, 2005). A Vancouver police study (Wilson-Bates \& Chu, 2008) attributed the high rate of officer calls where mental illness was involved to a profound lack of mental health resources and capacity for information sharing. Similarly, in a police survey in eastern Ontario, over one third of respondents agreed that "if mental health services were adequate, police would not have to deal with the mentally ill" (Cotton, 2004, p. 139), and copious comments collected in a Toronto police survey attributed the increasing number of contacts to problems in the mental health system (Trovato, 2000). In a U.S. study of hospital ED referrals, Lee and colleagues (2008) suggested that mental health services may be falling short, because police presentations are more likely to occur at night and on weekends "when mental health services are at their most inaccessible" (p. 314). Watson, Morabito, Draine, and Ottati (2008) noted that a lack of community resources and alternative options may lead to "mercy booking" (p. 360), an arrest intended for the safety and care of the arrestee.

With this growing demand on police officers to respond to citizens in mental health crisis has come the recognition that police need better skills and tools for managing these encounters. One goal is to identify situations when alternatives to criminal sanctions should be made available. This concept is known as pre-arrest diversion. The police can influence whether individuals are transported or referred to treatment, remain in their current situation, or enter the criminal justice system. As such, the officer becomes a primary gatekeeper, determining whether the mental health or criminal justice system can best meet the needs of an individual with acute psychiatric problems (Lamb et al., 2002).

Over the last several decades, various strategies have been implemented to support better management of police encounters with mentally ill persons and pre-arrest diversion. While the research associated with these efforts has been largely descriptive rather than evaluative, a catalogue of promising practices is emerging (Council of State Governments USA, 2002; Hartford, Carey, \& Mendonca, 2006; Livingston, 2008). Key elements of these practices include training for dispatchers and front-line officers, appropriate on-scene response, access to no-refusal mental health crisis services and other follow-up supports as needed, and clear internal guidelines and protocols.

Dispatchers serve as the entry point into police services in that they receive and triage incoming calls. They need training for determining when a situation involves mental illness, assessing urgency and risk, dispatching the call to the appropriate police personnel along with relevant background information, and entering data about the call in the dispatch database.

Front-line police officers, as the primary service providers, need to be able to recognize incidents in which mental disorder may be a factor and provide the best possible response. To support their decisions, training is needed in identifying the behaviours indicative of mental disorder, interacting effectively with 
people who show psychiatric symptoms, using de-escalation techniques, assessing alternative responses, understanding powers under involuntary treatment legislation, and knowing about available community mental health resources. An important aspect of training is that it can alter attitudes as well as skills and behaviours. It can be provided at a basic level or a more advanced level for officers who may then be designated as first responders. Police and mental health agencies may collaborate in delivery of training (Hanafi, Bahora, Demir, \& Compton, 2008).

A number of on-scene response models for police encounters with persons with mental disorders have been developed. The basic difference among these models is whether mental health expertise is provided by police officers trained in mental health issues, or by mental health professionals who either co-respond with the officers or respond after the scene has been secured. The most common models, as outlined by many researchers (Hartford et al., 2006; Lamb et al., 2002; Livingston, 2008), are as follows:

- Specialized police intervention teams (also known as the Crisis Intervention Team [CIT] or Memphis model): Officers with special training in mental health issues (about 40 hours) are the first responders to the site. They defuse the situation and act as liaisons to the mental health system. The CIT model has been widely implemented in the United States.

- Joint response: A mobile crisis team consisting of police officers with extra training and mental health professionals respond together to situations that involve persons with mental disorders. The team may be either police service based or mental health service based.

- Mental health mobile crisis team (MCT model): Police develop a service agreement with a mobile crisis team based in the mental health system, which attends at the scene by request of the officer to stabilize and help decide a course of action.

The CIT model places a heavy reliance on rapid access to psychiatric emergency services, which ideally provide a no-refusal policy for police referrals, 24-hour access, and minimal wait time, and have the legal foundation to accept and detain individuals. In lieu of a dedicated centre, police services may negotiate "preferred status" with a local mental health crisis service that incorporates the preceding elements. All three models work best when police have protocols to make follow-up referrals to other services, including withdrawal management and assessment services (Hanafi et al., 2008; Hartford et al., 2006).

Internally, police services need clear policies and protocols to guide dispatcher and front-line officer responses and reporting practices (Livingston, 2008). Information systems must have the capacity to support police responses (e.g., at the time of the call provide details on high-risk individuals/repeat users and successful past interventions), as well as analyses of service trends (e.g., outcomes, repeat users) for evaluation and planning (Adelman \& Macnaughton, 2003; Lamb et al., 2002).

Police services in smaller communities with fewer local mental health resources may need to be more creative in how diversion supports are implemented, relying for example on remote training, accessing psychiatric consultation at a distance, and ensuring that staff who do attend at the site can handle a broad range of crises ("the expert generalist"; Forchuk, Jensen, Martin, \& Csiernik, 2008; Livingston, 2008). A Canadian survey indicated that most police services with formal programs for responding to people with mental illnesses were located in large urban centres (Cotton, 2004). 


\section{STUDY RATIONALE AND OBJECTIVES}

Ontario is the most populated Canadian province, with 12.2 million people (Statistics Canada, 2006) spread over a large geographic area. About 350 community organizations receive funding from the provincial Ministry of Health and Long-Term Care (the Ministry) to provide a range of services and supports to persons with mental illness, with no fees charged for these services. Policing services are provided by municipal services and by the Ontario Provincial Police, who work primarily in rural areas and on the highways. There are 68 municipal services in the province, with 17 serving population areas of 100,000 or more, and 36 serving areas of less than 15,000 people (Statistics Canada, 2008).

In recent years there has been increasing interest among Ontario police in improving practices for responding to people with mental illnesses. Regional and provincial Mental Health and Justice Coordinating Committees have been formed to support intersectoral collaboration, and partnerships with mental health services have developed to implement diversion programs (Landeen, Pawlick, Rolfe, Cottee, \& Holmes, 2004; Read, Rourke, \& Wasylenki, 2002). However, in Ontario there is no central provincial data source on the extent of police involvement with persons with mental illness or implementation of diversion practices. Two relatively recent surveys of Canadian police departments have been conducted on practices for managing mental health encounters but, to our knowledge, the Ontario results were not published. ${ }^{2}$

In 2004/05, the Ministry began a 4-year initiative to invest significant new funds in the community mental health system in Ontario. One portion was intended to generally increase system capacity related to crisis intervention, intensive case management, assertive community treatment, and early intervention for psychosis services. An additional portion, provided through a joint investment between the Ministries of Health, Attorney General, and Community Safety and Corrections, aimed at diverting persons with mental illness from the criminal justice system. Mental health organizations received funding to provide crisis outreach, short-term residential beds, court support services, intensive case management, and housing supports to persons at risk of legal involvement. In addition to expanding capacity, there was an expectation of increased collaboration between mental health and justice/corrections services, including the police, to achieve diversion.

The present study was conducted to learn more about police involvement with persons with mental illness, implementation of diversion practices, and changes that may have occurred since 2005 when the funding enhancements started. Since police activity is not reported to a central database in Ontario (each service collects data independently), a provincewide survey of individual police services was conducted to answer the following questions:

1. What is the volume of police contacts with people with mental illnesses (PMI), and has the volume changed over the study period?

2. What is the extent of use of pre-arrest diversion practices to manage police contacts with PMI, and has there been a change over the study period?

3. Do volume of contacts and practice implementation differ in large and small population areas?

The study received ethics approval from the Centre for Addiction and Mental Health Research Ethics Board. 


\section{METHODOLOGY}

\section{Survey Development}

A two-part survey was developed, drawing on the literature, input from mental health/police service stakeholders, and a recent international Internet survey of pre-arrest police programs (Hartford et al., 2006). The first section requested aggregated service data on annual volumes of police-citizen encounters for three indicators:

- incidents that involve people with mental illnesses,

- incidents that involve suicide attempts and completed suicides, and

- $\quad$ police apprehensions under the Ontario Mental Health Act (MHA). ${ }^{3}$

Data were requested for each of 5 years, from 2003 to 2007. Since processes for documenting occurrences and coding practices can vary across police services, ${ }^{4}$ for each indicator respondents were also asked to provide details on the administrative data source and codes, and on the process used for assigning codes. Also asked was whether the data system could provide additional information on encounters with an individual with mental illness, including previous contacts, outcomes of contacts, and officer time spent on the encounter.

The second section of the survey requested information on implementation of a number of practices and supports for dealing with persons with mental illness as suggested by the published literature. These included guidelines, training (in addition to what is offered to all officers by the Ontario Police College), onsite responses, and post-contact transfer of care. In addition, information was sought on perceived changes since 2005 when the new funding started to flow. More detail is provided in Table 1.

Two rounds of feedback on survey drafts were obtained from mental health providers and police officers related to relevance and clarity of items. Incorporation of their feedback supported the face and content validity of the final version of the tool.

\section{Data Collection}

An email invitation to complete a web-based survey was sent to the chief of every municipal police service in the province. Those who agreed were asked to pass the survey on to the appropriate staff for completion (typically, staff in the information and data services departments for Section 1 and the community services/planning and research departments for Section 2). Data collection occurred from October 2008 to February 2009. Participation was encouraged through multiple reminder emails sent from the study team and a newsletter sent from the Ontario Association of Chiefs of Police during that time.

A different process was followed with the OPP, because data collection is managed centrally for all 83 OPP detachments in the province. OPP central office staff answered Section 1 of the survey, but Section 2 was not completed as it was not possible to survey each detachment, in the time available, about their local diversion practices. 


\section{Table 1}

Police Services Survey Content

Section 1 (for staff in the information department)

Officer contacts with persons with mental illness 2003-2007

- volume of calls received and cleared that involved persons with mental illness

- volume of calls received and cleared that involved suicide threats, attempts, or jumps

- volume of calls received and cleared that involved completed suicide

- Mental Health Act apprehensions

Written guidelines for dealing with persons with mental illness

- for dispatchers and officers

Information systems

- contain information on person's past contacts with your service

- track outcomes

- track officer time

Section 2 (for staff in the community services department)

Training (when started, number of hours, who provides it)

- dispatchers

- front-line officers - basic training in addition to Ontario Police College

- front-line officers - intensive training for specialized officer role

On-site responses (when started, partners, how often used)

- designated officer with specialized training

- police officer and mental health professional (joint response)

- agreement with mental health mobile crisis team to assist at the site if requested

- access to on-site telephone consultation with mental health professional

Use of formal agreements for rapid transfer of care with

- hospital emergency department

- withdrawal management program

- community crisis program

Perceived changes (more, about the same, less) in past 3 years

- support for officers by mental health services

- participation in area mental health initiatives

- skills and time in managing PMI

- time managing contacts with PMI

Note. $\mathrm{PMI}=$ people with mental illness. 


\section{ANALYSIS}

Data from the web-based survey were imported into SPSS 15.0 for Windows. Contact data for the three indicators were reported as annual volumes for 2003 to 2007 and as population rates to take population growth into account. Weights were calculated for each service and the OPP based on the percentage of the 2006 Ontario population (Statistics Canada, 2006) living in their service catchment area. For each indicator, a repeated measures Analysis of Variance (ANOVA) was conducted to determine whether the Ontario change in rate/100,000 population over the 5-year study period was significant.

Use of diversion practices was reported as frequencies and percentages of responding services. Municipal police services were categorized as large area (catchment area $>100,000$ population) and small area (catchment area $<100,000$ population). For each practice, a chi-square test assessed differences in rate of practice implementation between large-area and small-area services.

\section{RESULTS}

Of the 68 municipal services in the province, 37 (54\%) completed the survey. Response rates were higher for large-area services (14/17 or $82 \%$ ) than for small-area services (23/51 or $45 \%)$. These 37 departments served $92 \%$ of population catchment area for the municipal police in Ontario. The OPP central office provided data for 75 out of 83 detachments, who served a combined population of 2.2 million Ontarians. Overall, the responding services provided good provincial population coverage (see Table 2).

Table 2

Police Service Responses 2003 and 2007, and Indicator Results 2007

\begin{tabular}{|c|c|c|c|c|c|}
\hline \multirow[t]{2}{*}{ Indicator } & \multirow{2}{*}{$\frac{2003}{\begin{array}{c}\text { Services } \\
\text { reporting }(n)\end{array}}$} & \multicolumn{4}{|c|}{2007} \\
\hline & & $\begin{array}{l}\text { Services } \\
\text { reporting }(n)\end{array}$ & $\begin{array}{l}\text { Population } \\
\text { coverage }^{\mathrm{a}}\end{array}$ & $\begin{array}{l}\text { Indicator } \\
\text { result }(n)\end{array}$ & $\begin{array}{c}\text { Rate (per } \\
100 \mathrm{~K} \text { pop) }\end{array}$ \\
\hline \multicolumn{6}{|c|}{ Contacts that involved mental illness ${ }^{\mathrm{b}}$} \\
\hline Municipal services & 25 & 33 & $9.3 \mathrm{M}$ & 34,248 & 368 \\
\hline OPP detachments & 75 & 75 & $2.2 \mathrm{M}$ & 5,984 & 269 \\
\hline Total & 100 & 108 & $11.5 \mathrm{M}$ & 40,232 & 349 \\
\hline \multicolumn{6}{|c|}{ Suicide-related contacts ${ }^{\mathrm{b}}$} \\
\hline Municipal & 30 & 35 & $8.6 \mathrm{M}$ & 8,996 & 105 \\
\hline OPP & 75 & 75 & $2.2 \mathrm{M}$ & 2,624 & 118 \\
\hline Total & 105 & 110 & $10.8 \mathrm{M}$ & 11,620 & 108 \\
\hline \multicolumn{6}{|l|}{ MHA apprehensions } \\
\hline Municipal & 22 & 27 & $7.8 \mathrm{M}$ & 16,021 & 205 \\
\hline OPP & NA & NA & NA & NA & NA \\
\hline Total & 22 & 27 & $7.8 \mathrm{M}$ & 16,021 & 205 \\
\hline
\end{tabular}

Note. $\mathrm{MHA}=$ Mental Health Act; $\mathrm{NA}=$ not available.

${ }^{\mathrm{a}}$ Out of provincial population of 12.2 million in $2006 .{ }^{\mathrm{b}} \mathrm{Calls}$ that were received and cleared. 
One aim of the survey was to assess how many services were able to provide the requested data. As Table 2 indicates, over the study period this number increased across all three indicators. However, the ability to report MHA apprehension data was the lowest. Even in 2007 this information was provided by only 27 of the 37 municipal services (73\%), and the OPP could not report it. Regarding volume of contacts, Table 2 indicates substantial police involvement related to mental health in 2007, with the study sample reporting over 40,000 mental health-related encounters (349/100,000 population), almost 12,000 suicide-related contacts (108/100,000 population), and over 16,000 MHA apprehensions (205/100,000 population).

Table 3 provides indicator results for 2003 to 2007 for services that could report the results for all 5 years. Rates of contact with PMI rose from 287 (2003) to 397 (2007) per 100,000 population overall, from 328 to 443 for municipal police, and from 177 to 269 for OPP. The rate change from 2003 to 2007 was

Table 3

Police-Citizen Encounters 2003-2007

\begin{tabular}{|c|c|c|c|c|c|c|}
\hline $\begin{array}{l}\text { Indicator } \\
\text { (\# services reporting } \\
\text { across all years) }\end{array}$ & Measure & 2003 & 2004 & 2005 & 2006 & 2007 \\
\hline \multicolumn{7}{|c|}{ Contacts that involved mental illness } \\
\hline Municipal services $(n=25)$ & $\begin{array}{l}\text { Volume } \\
\text { Rate }\end{array}$ & $\begin{array}{r}19,441 \\
328\end{array}$ & $\begin{array}{r}21,324 \\
357\end{array}$ & $\begin{array}{r}24,980 \\
413\end{array}$ & $\begin{array}{r}26,047 \\
427\end{array}$ & $\begin{array}{r}27,353 \\
443\end{array}$ \\
\hline $\operatorname{OPP}(n=75)$ & $\begin{array}{l}\text { Volume } \\
\text { Rate }\end{array}$ & $\begin{array}{r}3,934 \\
177\end{array}$ & $\begin{array}{r}4,808 \\
216\end{array}$ & $\begin{array}{r}5,395 \\
242\end{array}$ & $\begin{array}{r}5,403 \\
242\end{array}$ & $\begin{array}{r}5,984 \\
269\end{array}$ \\
\hline Total $(n=100)$ & $\begin{array}{l}\text { Volume } \\
\text { Rate }\end{array}$ & $\begin{array}{r}23,375 \\
287\end{array}$ & $\begin{array}{r}26,132 \\
318\end{array}$ & $\begin{array}{r}30,375 \\
367\end{array}$ & $\begin{array}{r}31,450 \\
377\end{array}$ & $\begin{array}{r}33,337 \\
397\end{array}$ \\
\hline \multicolumn{7}{|l|}{ Suicide-related contacts } \\
\hline Municipal services $(n=30)$ & $\begin{array}{l}\text { Volume } \\
\text { Rate }\end{array}$ & $\begin{array}{r}7,487 \\
121\end{array}$ & $\begin{array}{r}7,750 \\
124\end{array}$ & $\begin{array}{r}7,907 \\
125\end{array}$ & $\begin{array}{r}7,221 \\
113\end{array}$ & $\begin{array}{r}7,204 \\
112\end{array}$ \\
\hline $\mathrm{OPP}(n=75)$ & $\begin{array}{l}\text { Volume } \\
\text { Rate }\end{array}$ & $\begin{array}{r}2,298 \\
103\end{array}$ & $\begin{array}{r}2,480 \\
111\end{array}$ & $\begin{array}{r}2,551 \\
114\end{array}$ & $\begin{array}{r}2,553 \\
115\end{array}$ & $\begin{array}{r}2,627 \\
118\end{array}$ \\
\hline Total $(n=105)$ & $\begin{array}{l}\text { Volume } \\
\text { Rate }\end{array}$ & $\begin{array}{r}9,785 \\
116\end{array}$ & $\begin{array}{r}10,230 \\
121\end{array}$ & $\begin{array}{r}10,458 \\
122\end{array}$ & $\begin{array}{r}9,774 \\
114\end{array}$ & $\begin{array}{r}9,831 \\
114\end{array}$ \\
\hline \multicolumn{7}{|l|}{ MHA apprehensions } \\
\hline Municipal services $(n=23)$ & $\begin{array}{l}\text { Volume } \\
\text { Rate }\end{array}$ & $\begin{array}{l}\text { NA } \\
\text { NA }\end{array}$ & $\begin{array}{r}10,219 \\
172\end{array}$ & $\begin{array}{r}12,138 \\
203\end{array}$ & $\begin{array}{r}12,934 \\
213\end{array}$ & $\begin{array}{r}14,214 \\
232\end{array}$ \\
\hline $\mathrm{OPP}(n=75)$ & $\begin{array}{l}\text { Volume } \\
\text { Rate }\end{array}$ & $\begin{array}{l}\text { NA } \\
\text { NA }\end{array}$ & $\begin{array}{l}\text { NA } \\
\text { NA }\end{array}$ & $\begin{array}{l}\text { NA } \\
\text { NA }\end{array}$ & $\begin{array}{l}\text { NA } \\
\text { NA }\end{array}$ & $\begin{array}{l}\text { NA } \\
\text { NA }\end{array}$ \\
\hline Total $(n=23)$ & $\begin{array}{l}\text { Volume } \\
\text { Rate }\end{array}$ & $\begin{array}{l}\text { NA } \\
\text { NA }\end{array}$ & $\begin{array}{r}10,219 \\
172\end{array}$ & $\begin{array}{r}12,138 \\
203\end{array}$ & $\begin{array}{r}12,934 \\
213\end{array}$ & $\begin{array}{r}14,214 \\
232\end{array}$ \\
\hline
\end{tabular}

Note. The table includes data only for services that could report for all 5 years. The rate is weighted rate per 100,000 population for responding services. $\mathrm{MHA}=$ Mental Health Act; $\mathrm{NA}=$ not available. 
statistically significant only for the OPP, $F(2.51,185.36)^{5}=25.62, p<.001$. Post hoc $t$-test results indicated a statistically significant rate increase between 2003 and 2007, $t(74)=6.83, p<.001$. Rates of suicide-related contacts declined slightly for municipal services and increased slightly for the OPP, with an overall effect of minimal change per 100,000 population (116 in 2003 versus 114 in 2007), and were not statistically significant $(F<1.69, p>$.10). MHA apprehension rates for municipal police increased over the study period, but the changes were not significant, $F(1.18,24.83)=3.08, p=.09$.

Figure 1 compares results for large- and small-area services. Rates and trends over time were similar for mental health contacts and MHA apprehensions. Suicide-related contacts declined for small-area services, but in 2007 the rates for large- and small-area services were similar.

Figure 1

Encounters With PMI for Large- and Small-Area Municipal Police Services, 2003-2007

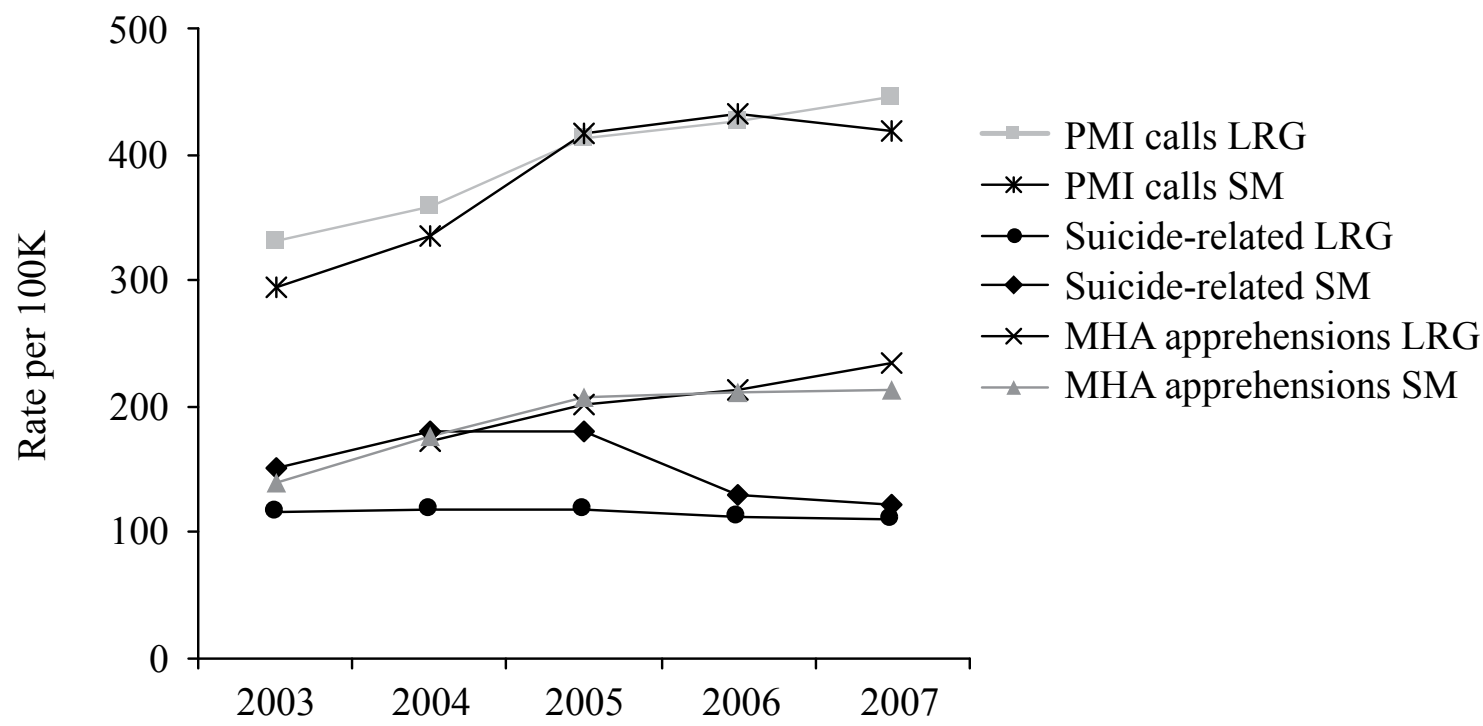

Note. $\mathrm{PMI}=$ people with mental illness; $\mathrm{LRG}=$ large-area municipal police services; $\mathrm{SM}=$ small-area municipal police services; MHA $=$ Mental Health Act.

Table 4 indicates the extent to which police services provided diversion practices and supports. Rates are reported for all municipal police services in the sample, and then for large- and small-area services.

Over half of the services provided mental health training to dispatchers (21/37), although the length of training varied widely from 1 to 40 hours. Thirty-one services (84\%) provided basic training to frontline officers, and $13(35 \%)$ provided intensive training to a subgroup of front-line "specialty" officers. The length of basic training was 5 hours or less for almost all services (27/31), and was usually delivered 
through a partnership with mental health professionals (22/31). The intensive training was more variable in length; only 7/13 services reported providing 40 hours of training, which is the recommended length for CIT officer training (Cotton \& Coleman, 2008). Intensive training was delivered through a partnership with mental health professionals by all 13 services. Training was significantly more likely to be provided in large- than small-area services. Among the services that provided training, the portion of staff who had been trained within the last 2 years was $70 \%$ for dispatchers, $59 \%$ for front-line staff, and $27 \%$ for specialty staff (not shown in table).

Table 4

Practices for Managing Encounters for Mental Illness - Municipal Police

\begin{tabular}{|c|c|c|c|}
\hline \multirow[t]{2}{*}{ Practice } & \multicolumn{3}{|c|}{ Rate of implementation (\% services) } \\
\hline & $\begin{array}{l}\text { All services } \\
\quad N=37\end{array}$ & $\begin{array}{c}\text { Large-area services } \\
\qquad N=14\end{array}$ & $\begin{array}{c}\text { Small-area services } \\
\qquad N=23\end{array}$ \\
\hline \multicolumn{4}{|l|}{ Training } \\
\hline Dispatchers & 57 & 79 & $43^{*}$ \\
\hline Basic front-line officer training & 84 & 100 & $74 *$ \\
\hline Intensive front-line officer training & 35 & 71 & $13^{*}$ \\
\hline \multicolumn{4}{|l|}{ On-site responses } \\
\hline Access to mobile MH team & 62 & 86 & $48^{*}$ \\
\hline Access to telephone consultation & 57 & 79 & $43^{*}$ \\
\hline Joint police-MH response & 49 & 86 & $26^{*}$ \\
\hline Designated police officer & 30 & 64 & $9 *$ \\
\hline At least one on-site response & 81 & 100 & $70^{*}$ \\
\hline \multicolumn{4}{|l|}{ Post-event referral agreement with ... } \\
\hline Hospital emergency service & 35 & 36 & 35 \\
\hline Community crisis service & 30 & 43 & 22 \\
\hline Withdrawal management service & 19 & 29 & 13 \\
\hline \multicolumn{4}{|l|}{ Information system data } \\
\hline Previous contacts & 97 & 100 & 96 \\
\hline Outcome of encounter & 41 & 57 & 30 \\
\hline Officer time & 54 & 71 & 43 \\
\hline \multicolumn{4}{|l|}{ Written guidelines } \\
\hline For dispatchers & 76 & 79 & 74 \\
\hline For front-line officers & 95 & 100 & 91 \\
\hline
\end{tabular}

Note. $\mathrm{MH}=$ mental health.

* Significant chi-square test results with $d f=1, p<.05$. 
Regarding on-site responses, $62 \%$ of services had agreements with mobile mental health teams to assist at the site, $57 \%$ had access to on-site telephone consultation with mental health professionals, $49 \%$ had a police-mental health joint-response program, and 30\% had a designated officer response. Overall, $81 \%$ of the sample had implemented at least one of these four responses. Again, across all response types, implementation rates were significantly higher for large-area services, including the specialized officer response, which very few small-area services have implemented. All large-area services had implemented at least one of these responses compared with $70 \%$ of small-area services. Services that had an on-site response in place were asked how often the response was used when a contact involved PMI. As indicated in Table 5, actual use was low, with about half of police services using the response in fewer than $25 \%$ of encounters. Use was lowest for the designated officer response.

Overall the portion of services reporting formal agreements to facilitate citizen transfer for follow-up care was low-35\% had agreements with hospital emergency, 30\% with community crisis, and 19\% with withdrawal management services - and any differences between large- and small-area services were not significant.

Regarding information systems, most police services said they could report previous contacts, but fewer could report outcomes or staff time spent on the encounter. Large-area services were more likely to have these data than small-area services, but differences were not significant. Finally, most services had written guidelines to assist officer response when mental illness was involved. Fewer had guidelines for dispatchers, and there were almost no differences between large- and small-area services.

Table 6 reports the portion of services implementing diversion practices prior to and since 2005. After 2005, more departments were offering training, especially to front-line officers (additional 15 services), on-site diversion responses (additional 8-10 services), and agreements for follow-up transfer of care (additional 2-6 services). In most cases the current number of police services providing the practice was double or more the number in 2005. As shown in Table 7, perceived support from and involvement with mental health organizations also increased, as did perceived ability to manage mental health contacts and time spent in these encounters.

Table 5

Frequency of Use of On-Site Diversion Practices - Municipal Police

\begin{tabular}{lccccc}
\hline On-site response & \multicolumn{5}{c}{ Frequency of use } \\
\cline { 2 - 6 } & $\begin{array}{c}<25 \% \text { of } \\
\text { incidents } \\
n(\%)\end{array}$ & $\begin{array}{c}25-50 \% \text { of } \\
\text { incidents } \\
n(\%)\end{array}$ & $\begin{array}{c}50-75 \% \text { of } \\
\text { incidents } \\
n(\%)\end{array}$ & $\begin{array}{c}\text { Almost } \\
\text { always } \\
n(\%)\end{array}$ & $\begin{array}{c}\text { Don't } \\
\text { know } \\
n(\%)\end{array}$ \\
\hline Mobile $(n=23)$ & $10(44 \%)$ & $4(17 \%)$ & $3(13 \%)$ & $2(9 \%)$ & $4(17 \%)$ \\
Telephone consultation $(n=21)$ & $10(48 \%)$ & $3(14 \%)$ & $2(10 \%)$ & $2(10 \%)$ & $4(19 \%)$ \\
Joint $(n=18)$ & $8(44 \%)$ & $2(11 \%)$ & $3(17 \%)$ & $2(11 \%)$ & $3(17 \%)$ \\
Designated officer $(n=11)$ & $7(64 \%)$ & $0(0 \%)$ & $0(0 \%)$ & $2(18 \%)$ & $2(18 \%)$ \\
\hline
\end{tabular}


Table 6

Practice Implementation Prior to and Since 2005 (\% Municipal Police Services)

\begin{tabular}{lccccc}
\hline Practice (N=37 municipal services) & $\begin{array}{c}\text { Offered } \\
\text { at all }\end{array}$ & $\begin{array}{c}\text { Offered } \\
\text { since 2005 }\end{array}$ & $\begin{array}{c}\text { Offered } \\
\text { prior 2005 }\end{array}$ & $\begin{array}{c}\text { Offered (year } \\
\text { not known) }\end{array}$ & $\begin{array}{c}\text { Not } \\
\text { offered }\end{array}$ \\
\hline $\begin{array}{l}\text { Training } \\
\text { Dispatchers }\end{array}$ & 57 & 16 & 41 & - & 43 \\
Front-line officers & 84 & 41 & 43 & - & 16 \\
Specialty officers & 35 & 22 & 13 & - & 62 \\
On-site responses & & & & & \\
Specialty officer & 30 & 19 & 11 & - & 70 \\
Joint & 49 & 22 & 27 & - & 51 \\
Mobile & 62 & 27 & 27 & 8 & 38 \\
Telephone & 57 & 27 & 19 & 11 & 43 \\
& & & & & \\
Post-encounter referral agreements with... & & & & & \\
$\quad$ Hospital emergency rooms & 35 & 14 & 14 & 5 & 65 \\
Community crisis programs & 30 & 11 & 14 & 5 & 81 \\
Withdrawal management & 19 & - & 14 & & 5 \\
\hline
\end{tabular}

Table 7

Perceived Changes in Mental Health (MH) System Support Since 2005

\begin{tabular}{lccc}
\hline Skills and MH system support $(N=37$ municipal services) & $\begin{array}{c}\text { More } \\
(\%)\end{array}$ & $\begin{array}{c}\text { Same } \\
(\%)\end{array}$ & $\begin{array}{c}\text { Less } \\
(\%)\end{array}$ \\
\hline Participation in area MH initiatives & 70 & 30 & 0 \\
Support from MH services & 57 & 38 & 5 \\
Officer ability to manage MH contacts & 54 & 46 & 0 \\
Officer time managing MH contacts & 41 & 43 & 16 \\
\hline
\end{tabular}

\section{DISCUSSION}

Increased diversion of persons with mental illness from the criminal justice system was a key goal of recent new funding provided through an interministerial collaboration that involved Health and Long-Term Care, the Attorney General, and Community Safety and Corrections. The present study was conducted to learn more about police encounters with PMI in Ontario, implementation of practices to support diversion, and any changes that may have occurred after the new funding began to flow.

The results indicated substantial involvement by Ontario police in diversion programming. Many services provide mental health training to front-line staff and about half provide training to dispatchers. Similarly, 
most services have guidelines in place to support officer responses when mental illness is involved, and about half have dispatcher guidelines. The vast majority of services have at least one on-site diversion response in place, with collaboration with mental health mobile teams being most common. This contrasts sharply with the results of an earlier Canadian survey where only a small minority of Canadian police services had formal diversion strategies in place (Cotton, 2004).

Much of this implementation activity has occurred since 2005. Also reported since 2005 is a police perception of more collaboration with and support from mental health services and better officer skills for handling encounters with PMI. These changes coincide with the entry of new funding into the community mental health system, although no link can be made based on the study methodology. This activity also coincides with strong policy support in the province for diversion and the widespread implementation of collaborative human service and justice coordinating committees. Still, the new funding may have provided additional motivation and some practical resources for moving forward on this policy issue.

Despite having many diversion practices in place, implementation was variable. For example, while many services had a mental health training program in place, there was wide variation in the number of training hours and the percentage of staff who received the training. A recent Canadian review of police academy training for new recruits on interactions with people with mental illnesses (Cotton \& Coleman, 2008) commended inclusion of this topic in every organization's training curriculum but similarly noted wide variation in the number of training hours, content, and teaching techniques. Study recommendations included developing a common mental health core curriculum for all police academies; using competency and problem-based learning methods; and involving people living with a mental illness, their families, and mental health professionals in delivery of the training program.

Regarding on-site responses, many services had a practice in place but actual use was low. This could reflect a capacity issue (e.g., timely availability of specialist officer or mobile mental health team); an awareness/uptake issue (individual officers may not be familiar with or interested in specialist mental health support); or a need/triage issue (incidents may not be perceived as requiring mental health expertise or may be resolved quickly on site). The explanation is beyond the scope of this study but is an important area for follow-up inquiry.

Consistent with the literature, results also indicate lower uptake of training and on-site diversion practices in small-area services. This is a concern as the encounter data indicated that the rate of police contact with PMI was as high for small-area services as for large-area services. Forchuk et al. (2008) have noted the importance of customizing the diversion responses to the geography of the area which, in more rural areas, may require mobile approaches to provide timely response across potentially large distances. In the present study, co-response and specialist officer approaches were least likely to be used, suggesting that these responses may be less feasible for rural areas. The number of agreements for follow-up care also was lower in small-area services, which potentially puts more pressure on the police responders to reach a stable resolution and places greater demands on their time. Consistent with this, Cotton and Coleman (2008) suggested that police services in smaller and remote areas may need more mental health training than those in areas where dedicated mental health teams and specialized services are available. 
One of the expected goals of increasing the capacity of community mental health services was that fewer mental health crises would conclude with a visit to a hospital emergency service or with police contact. The surveyed police services reported over 40,000 police contacts with PMI in 2007 and over 16,000 MHA apprehensions. While not statistically significant, the data indicated a steady increase since 2003. It is possible that the increase is a result of better recognition by officers of mental health issues or a change in how officers report these contacts, but there may also be a real increase in demand. A separate study on the impact of the new funding found an increase in hospital emergency department visits for mental health conditions over the study period (Durbin, Lin, \& Zaslavska, 2010). Further, evaluation studies of specific programs that received the new funding (for either home care or diversion) found that, while program capacity increased over the study period, there was still considerable unmet need for service in the system (Dewa et al., 2008; Stuart, Krupa, \& Koler, 2008). It is possible then that the increasing demand on police found in this study reflects the high level of unmet need that still exists in the community.

Suicide-related contacts were relatively stable over the study period. This finding contrasts with results of an earlier Toronto study that found a steady increase in calls to police for suicidal behaviour from 1997 to 2001 (Matheson et al., 2005). It is possible that management of this very serious mental health issue was a particular focus of recipients of the new funding. Still, at over 11,000 calls, police are assuming a major role in responding to this problem. Not only is the police time associated with this type of call considerable (Matheson et al., 2005), police response also is potentially inappropriate for a situation that is challenging even for a skilled mental health professional with a high level of training and experience. Whether the police are more likely to involve mental health professionals in suicide-related calls is a question that could be further explored with the police and by examining encounter-level data.

Good access to follow-up mental health care has been identified as important for diversion to be successful (Lamb \& Weinberger, 2005). Rapid transfer of care to either a hospital emergency department or a community crisis program is particularly vital. Yet few of the surveyed services in the present study had agreements in place for transfer of care with hospitals, community crisis programs, or withdrawal management services. Lack of follow-up options, especially for rapid transfer, can be a deterrent to police to practice diversion (Wilson-Bates $\& \mathrm{Chu}, 2008$ ). It can also be a safety concern if officers spend long periods of time in the emergency room rather than out in the community (Forchuk et al., 2008). Pertaining to this latter issue, Gotlib (2007) has described several Ontario hospital emergency department initiatives that have reduced average wait times for police to an hour or less.

The number of police services that provided the indicator data was greater for 2007 than for 2003. It appears that individual services are developing better information systems to support and monitor encounters that involve mental illness. A next step could explore data quality and standardization across services and the potential for moving to a common minimum dataset to monitor diversion activity across the province, learn about service successes and challenges, and inform efforts to improve diversion training and responses. If encounter-level data were collected, the link between citizen presentation (e.g., suicidality) and police response could be examined. Encounter-level data items could include type of problem, time spent on encounters, and outcomes of encounters (e.g., arrest, on-site management, volunteer referral to mental health treatment, apprehension). Service-level data could capture details about training and on-site responses, perhaps building 
on the present survey. Data quality related to police recognition of contacts that involve mental illness will be a continuing challenge. Hoch and colleagues (Hoch, Hartford, Heslop, \& Stitt, 2009) developed an algorithm to identify encounters with persons with severe mental illness, using administrative data that did not rely solely on officer judgment. On the other hand, Wilson-Bates and Chu (2008) argued for the utility of identifying cases based on subjective assessment as it is this opinion that will guide officer actions.

\section{LIMITATIONS}

Limitations in the survey methodology and data sources need to be considered when interpreting findings. Pertaining to the indicator data, police services provided aggregated results from their administrative databases. Associations at the encounter level (e.g., between type of call and police response) could not be examined. No interrater data quality checks could be performed. As previously noted, recognition and reporting by officers of encounters that involve mental illness depend on many variables including knowledge, judgment, and coding priorities. As such the provincial-level indicator results reported are appropriately interpreted as general estimates of current police involvement with PMI and trends over time. Developing more precise descriptions of these contacts will depend on better data quality, driven by standardized recording and monitoring practices. In addition, completion of the survey was the responsibility of one individual in each service. The small subset of questions based on perceptions (e.g., change over time in mental health system collaboration) or estimates (percentage of encounters where diversion response was used) reflect the view of only one individual, and the total sample was small. Also, the survey was not structured to capture the heterogeneity of practice that is likely present in larger services with multiple divisions, or the practice details that are needed to characterize better practices. Population coverage was good, but response rates from very small area municipal services were low and OPP detachment information on diversion practices was not reported.

\section{CONCLUSION}

Police services in Ontario have a range of practices in place to support management of persons with mental illness. Some of these practices have been implemented during the last 5 years, coinciding with the entry in 2005 of new resources into the community mental health system for diversion, although other system activities during the period have also promoted police-mental health system collaboration and pre-arrest diversion efforts. During the study period 2003-2007, there was also a trend of an increased volume of police encounters involving individuals with mental illness, possibly reflective of high levels of unmet need for service that the new community resources were only partially able to address. Police service ability to report data improved over the study period, but data quality is a concern due to lack of common reporting practices across services. Continuing work to create a provincial standardized database of police-citizen encounter data would facilitate efforts to better understand when and how diversion practices are implemented and with what results, and would be one means of keeping this important policy goal on the agenda of services and government. 


\section{POLICE-CITIZEN ENCOUNTERS THAT INVOLVE MENTAL HEALTH CONCERNS}

\section{NOTES}

1. Reports of large numbers of persons with mental illness in American jails and prisons began appearing in the 1970s, a phenomenon that had not been reported since the 19th century (National Alliance on Mental Illness, 2008).

2. An international survey with responses from 30 Canadian services (Hartford et al., 2006), and a 2001 unpublished Canadian survey of police/mental health agency liaison models by Cotton (cited in Cotton, 2004).

3. Under the Ontario Mental Health Act, if on a reasonable grounds an officer believes that a person is suffering from emotional disturbance or mental illness, the officer may apprehend and bring the person to a medical facility (psychiatric, if possible) for examination by a physician. During the apprehension the officer must adhere to the procedure set out in the Act and retain custody of the person until the facility is able to take him or her (Service Ontario, 1990; Walma \& West, 2002).

4. Generally, after an officer-citizen encounter, the officer completes an incident or arrest report, which is often recorded in an electronic records management system.

5. Degrees of freedom for all ANOVAs were corrected using Greenhouse-Geisser estimates of sphericity.

\section{RÉSUMÉ}

Cette étude nous a permis de faire une enquête auprès des services de police, en Ontario, pour évaluer les changements survenus, entre 2003 et 2007 (période au cours de laquelle un financement supplémentaire significatif a été injecté dans le système de santé mentale communautaire), dans le nombre d'interventions touchant des personnes ayant des problèmes de santé mentale et l'utilisation de pratiques de pré-arrestation et de non-judiciarisation. Les services de police de 37 municipalités (54\% des services, desservant $92 \%$ de la population de la province) et la Police provinciale de l'Ontario ont participé à cette enquête. Nos observations indiquent que le nombre d'interventions de la police auprès de personnes ayant des problèmes de santé mentale a augmenté. Les policiers disposaient d'une gamme de procédures autres que l'arrestation et la judiciarisation, mais, dans la pratique, l'utilisation de ces procédures était peu répandue. Certaines de ces procédures ont effectivement été mises en place après 2005, c'est-à-dire au moment de l'injection du nouveau financement ; mais, au même moment, d'autres efforts ont été faits pour encourager la collaboration entre la police et le système de santé mentale et les pratiques de pré-arrestation et de non-judiciarisation. La capacité de la police à transmettre ce type de données s'est accrue durant la période étudiée, mais ce n'est pas encore une pratique courante. Il est donc nécessaire de poursuivre le travail pour établir une banque de données provinciale standardisée des interventions de la police auprès des citoyens, pour que nous puissions mieux comprendre quand et comment des pratiques de non-judiciarisation sont mises en place et avec quels résultats.

\section{REFERENCES}

Adelman, J., \& Macnaughton, E. (2003). Study in blue and grey. Police interventions with people with mental illness: A review of challenges and responses. Vancouver: Canadian Mental Health Association, BC Division. Retrieved from http://www.cmha.bc.ca/files/policereport.pdf

Bland, R.C., Newman, S.C., Thompson, A.H., \& Dyck, R.J. (1998). Psychiatric disorders in the population and in prisoners. International Journal of Law and Psychiatry, 21, 273-279.

Borum, R. (2000). Improving high risk encounters between people with mental illness and the police. The Journal of the American Academy of Psychiatry and the Law, 28, 332-337.

Borum, R., Deane, M.W., Steadman, H.J., \& Morrissey, J.P. (1998). Police perspectives on responding to mentally ill people in crisis: Perceptions of program effectiveness. Behavioral Sciences and the Law, 16, 393-405.

Cordner, G. (2006). People with mental illness (Guide No. 40). Problem-oriented guides for police. Problem-specific guides series. Retrieved from http://www.popcenter.org/problems/mental_illness/ 
Cotton, D. (2004). The attitudes of Canadian police officers toward the mentally ill. International Journal of Law and Psychiatry, 27, 135-146.

Cotton, D., \& Coleman, T. (2008). A study of police academy training and education for new police officers related to working with people with mental illness. Report prepared on behalf of the Canadian Association of Chiefs of Police and the Mental Health Commission of Canada. Retrieved from http://www.pmhl.ca/webpages/reports/ AApoliceacademy.pdf

Council of State Governments USA.(2002). Criminal justice/mental health consensus project . Retrieved from http://consensus project.org/

Crocker, A.G., Hartford, K., \& Heslop, L. (2009). Gender differences in police encounters among persons with and without serious mental illness. Psychiatric Services, 60, 86-93.

Deane, M.W., Steadman, H.J., Borum, R., Veysey, B.M., \& Morrissey, J.P. (1999). Emerging partnerships between mental health and law enforcement. Psychiatric Services, 50, 99-101.

Dewa, C., Chau, N., deRuiter, W., Loong, D., Trojanowski, L., and Yip, A. (2008). Examining the effects of enhanced funding for specialized programs (Court Support Programs Wave 3 Report. SEEI Final Project Report). Retrieved from https//www.ehealthontario.ca

Durbin, J., Lin, E., \& Zaslavska, N. (2010). The impact study. Retrieved from www.ehealthontario.ca

Forchuk, C., Jensen, E., Martin, M., \& Csiernik, R. (2008). Crisis services: A comparative approach to evaluation (SEEI Final Project Report). Retrieved from https://www.ehealthontario.ca

Fry, M., \& Brunero, S. (2005). The characteristics and outcomes of mental health patients presenting to an emergency department over a twelve month period. Australian Emergency Nursing Journal, 27, 21-25.

Gotlib, D. (2007). Police, the emergency department, and the suicidal patient: Towards more effective collaboration between police and hospital emergency services in the care of the suicidal patient. Oakville, ON: Association of General Hospital Psychiatric Services.

Hanafi, S., Bahora, M., Demir, B.N., \& Compton, M.T. (2008). Incorporating crisis intervention team (CIT) knowledge and skills into the daily work of police officers: A focus group study. Community Mental Health Journal, 44, 427-432.

Hartford, K., Carey, R., \& Mendonca, J. (2006). Pre-arrest diversion of people with mental illness: Literature review and international survey. Behavioral Sciences and the Law, 24, 845-856.

Hoch, J., Hartford, K., Heslop, L., \& Stitt, L. (2009). Mental illness and police interactions in a mid-sized Canadian city: What the data do and do not say. Canadian Journal of Community Mental Health, 28, 49-66.

Lamb, H.R., \& Weinberger, L.E. (2005). The shift of psychiatric inpatient care from hospitals to jails and prisons. Journal of the American Academy of Psychiatry and the Law Online, 33, 529-534.

Lamb, H.R., Weinberger, L.E., \& DeCuir, W.J., Jr. (2002). The police and mental health. Psychiatric Services, 53, 1266-1271.

Landeen, J., Pawlick, J., Rolfe, S., Cottee, I., \& Holmes, M. (2004). Delineating the population of a mobile crisis team: Organizing diversity. Canadian Journal of Psychiatry, 49, 45-50.

Lee, S., Brunero, S., Fairbrother, G., \& Cowan, D. (2008). Profiling police presentations of mental health consumers to an emergency department. International Journal of Mental Health Nursing, 17, 311-316.

Livingston, J.D. (2008). Criminal justice diversion for persons with mental disorders. A review of best practices. Vancourver: Canadian Mental Health Associaiton, BC Division.

Matheson, F.I., Creatore, M.I., Gozdyra, P., Moineddin, R., Rourke, S.B., \& Glazier, R.H. (2005). Brief reports: Assessment of police calls for suicidal behavior in a concentrated urban setting. Psychiatric Services, 56, 1606-1609.

National Alliance on Mental Illness. (2004). Emergency departments see dramatic increase in people with mental illness seeking care. Retrieved from http://www.nami.org/

National Alliance on Mental Illness. (2008). Decriminalizing mental illness: Background and recommendations. Retrieved from http://www.nami.org/Content/ContentGroups/ Policy/Issues_Spotlights/Criminalization /forensic_taskforce_paper_8-29-2008.pdf

Priebe, S., Badesconyi, A., Fioritti, A., Hansson, L., Kilian, R., Torres-Gonzales, F., . . . Wiersma, D. (2005). Reinstitutionalisation in mental health care: Comparison of data on service provision from six European countries. British Medical Journal, 330(7483), 123-126. 


\section{POLICE-CITIZEN ENCOUNTERS THAT INVOLVE MENTAL HEALTH CONCERNS}

Read, N.E., Rourke, S.B., \& Wasylenki, D. (2002). Mobile crisis intervention in the inner city (abstract). Journal of Urban Health: Bulletin of the New York Academy of Medicine, 79, S87-S94.

Redondo, R.M., \& Currier, G.W. (2003). Emergency psychiatry: Characteristics of patients referred by police to a psychiatric emergency service. Psychiatric Services, 54, 804-806.

Service Ontario. (1990). Mental Health Act. Retrieved from http://www.e-laws.gov.on.ca/html/statutes/english /elaws_statutes_90m07_e.htm

Statistics Canada. (2006). Census of Canada 2006. Retrieved from http://www12.statcan.gc.ca/census-recensement /index-eng.cfm

Statistics Canada. (2008). Police resources in Canada, 2008. Retrieved from http://www.statcan.gc.ca/pub/85225-x/2008000/part-partie1-eng.htm

Stuart, H., Krupa, T., \& Koler, M. (2008). Do clients receive more appropriate care and use fewer hospital resourses now that the system has been enhanced? Retrieved from https://ozone.scholarsportal.info/bitstream/1873/15344/1/294295 .pdf

Trovato, F. (2000). Community policing and the emotionally disturbed persons (EDPs): Are we meeting their needs? (Unpublished master's thesis), Niagara University, New York.

Waldman, A. (2004). Police struggle with approach to the mentally ill. The Christian Science Monitor, March 17. Retrieved from http://www.csmonitor.com/2004/0317/p11s02-usju.html

Walma, M., \& West, L. (2002). Police powers and procedures. Toronto: Emond Montromery Publications.

Watson, A.C., Morabito, M.S., Draine, J., \& Ottati, V. (2008). Improving police response to persons with mental illness: A multi-level conceptualization of CIT. International Journal of Law and Psychiatry, 31, 359-368.

Wilson-Bates, F., \& Chu, J. (2008). Lost in transition: How a lack of capacity in the mental health system is failing Vancouver's mentally ill and draining police resources. Vancouver: Vancouver Police Board. 
กิ 